Revue bibliographique pour le domaine irano-aryen

\title{
Rudi Matthee, Elena Andreeva (eds.). Russians in Iran: diplomacy and power in the Qajar era and beyond
}

\section{Alisa Shablovskaia}

\section{(2) OpenEdition}

1 Journals

\section{Édition électronique}

URL : http://journals.openedition.org/abstractairanica/50306

DOI : 10.4000/abstractairanica.50306

ISBN : 1961-960X

ISSN : 1961-960X

Éditeur :

CNRS (UMR 7528 Mondes iraniens et indiens), Éditions de l'IFRI

Référence électronique

Alisa Shablovskaia, «Rudi Matthee, Elena Andreeva (eds.). Russians in Iran: diplomacy and power in the Qajar era and beyond ", Abstracta Iranica [En ligne], Volume 40-41 | 2019, document 3, mis en ligne le 30 décembre 2019, consulté le 24 avril 2021. URL : http://journals.openedition.org/abstractairanica/ 50306 ; DOI : https://doi.org/10.4000/abstractairanica.50306

Ce document a été généré automatiquement le 24 avril 2021.

Tous droits réservés 


\title{
Rudi Matthee, Elena Andreeva (eds.). Russians in Iran: diplomacy and power in the Qajar era and beyond
}

\author{
Alisa Shablovskaia
}

\section{RÉFÉRENCE}

Rudi Matthee, Elena Andreeva (eds.). Russians in Iran: diplomacy and power in the Qajar era and beyond. London : I.B. Tauris \& Co. LTD, 2018, $320 \mathrm{p}$.

Ce volume édité par Rudi Matthee et Elena Andreeva constitue un apport remarquable dans le domaine des relations irano-russes et entre en dialogue avec le recueil d'études édité par Stephanie Cronin Iranian-Russian Encounters: Empires and Revolutions since 1800 publié en 2013. Ce travail collectif couvre une période historique assez longue de la fin de l'époque Safavide (1501-1736) jusqu'à l'abdication de Reza Shah (r. 1925-41). L'ouvrage est divisé en quatre parties qui suivent l'ordre chronologique et comporte treize chapitres, précédés par le préface de Rudi Matthee dans lequel il explicite les objectifs du livre : dépasser le récit de Great Game fondé sur le postulat de la compétition entre les « grandes puissances » pour la domination régionale; se pencher sur les trajectoires personnelles des individus impliqués dans les échanges irano-russes; développer une approche structurelle voir institutionnelle envers l'histoire des relations interétatiques et transfrontalières. Ces axes de recherche sont bien développés dans l'ouvrage qui fait émerger la diversité d'acteurs, de structures et d'institutions impliqués dans les échanges irano-russes. Les différends à l'intérieur de l'appareil diplomatique russe ainsi que les degrés d'indépendance des acteurs iraniens vis-à-vis des autorités étrangères sont les sujets qui apparaissent en filigrane tout au long du livre qui met en valeur des sources inédites. Toutefois, l'organisation des chapitres manque de cohérence méthodologique et en l'absence de conclusion le lecteur doit se confronter à la contradiction de certaines approches utilisées par les auteurs. Bien que le récit de Great Game soit, à juste titre, délaissé par les auteurs pour 
une vision plus nuancée de l'histoire régionale, les nouvelles modalités de l'analyse des relations tripartites entre la Russie, l'Iran et la Grande-Bretagne ne sont pas théorisées. Finalement, l'absence étonnante d'études traitant de la période correspondant à la convergence révolutionnaire irano-russe de 1917 à 1925 rend l'ouvrage relativement incomplet. Un compte-rendu critique détaillé est paru dans Studia Iranica 47/2 (2018) par Christian Bromberger.

2 Liste des articles :

3 1. Muriel Atkin. "The Early Stages of Russo-Iranian Relations", p. 11-23.

4 2. Soli Shahvar, Emil ABRAMOFF. "The Khan, the Shah, and the Tsar : The Khanate of Talesh between Iran and Russia”, p. 24-48.

5 3. Firuza Melville, "Alexander Sergeevich Griboedov : Russian Imperial James Bond Malgré lui. In Memory of the $25^{\text {th }}$ Anniversary of his Birth", p. 49-74.

6 4. Elena Andreeva. "Russian Government Action against Russian Deserters in Iran in the Nineteenth Century: Russian Orientalism at the State Level", p. 75-94.

7 5. Houri Berberian. "Nest of Revolution: The Caucasus, Iran and Armenians", p. 95-121.

8 6. Irina Pavlova. "The Loan and Discount Bank as an Agent of Russian Interests in Iran", p. $122-135$.

9 7. Rudi Matthee. "Infidel Aggression: The Russian Assault on the Holy Shrine of Imam Reza, Mashhad, 1912”, p. 136-172.

10 8. Nuzgar K. Ter-Oganov. "A Russian Officer's Letters on Russian and British Activities in Iran during World War I", p. 173-187.

11 9. Denis V. Volkov. "Vladimir Minorsky (1877-1966) and the Iran-Iraq War (1980-8) : The Centenary of 'Minorsky's Frontier”,' p. 188-216.

12 10. Lana Ravandi-Fadai. "Reconstructions of a Native in Exile Cossack Brigade Fighter and Architect of Tehran - Nikolai L'vovich Markov (1882-1957)", p. 217-242.

13 11. Mary Yoshinari. "From the Imperial Periphery to the Boundaries of power: Soviet diplomatic Officials in 1930s Iran", p. 243-275.

14 12. Rowena Abdul Razak. "Convenient Comrades: Re-assessing the Relationship between the Soviet Union and the Tudeh Party during the British-Soviet Occupation of Iran, 1941-5", p. 276-296.

15 13. Nikolay A. Kozhanov. "The USSR and the Allied Occupation of Iran in August 1941: The Untold Story of a Difficult Decision", p. 297-315.

\section{AUTEURS}

\section{ALISA SHABLOVSKAIA}

Doctorante Sorbonne Nouvelle, Mondes iranien et indien, Paris 